\title{
GOVERNMENT INTERVENTION ON ORGANIC FERTILIZER PROMOTION: A KEY TO ENHANCING SOIL HEALTH AND ENVIRONMENT
}

\author{
Sujan Amgai ${ }^{1}$, Santosh Raj Paudel ${ }^{2}$, Diwas Raj Bista ${ }^{3}$ and Salik Ram Poudel ${ }^{4}$
}

\begin{abstract}
Unilateral use of chemical fertilizers, devoid of organic sources, has led to gradual deterioration of soil health, exacerbating the agricultural productivity. This study focuses on the review the performance, effectiveness and modality of organic manure promotion programmes intervened by MoAD, using secondary datas. Major programmes intervened are: Vermi-compost production, cattle shed improvement, organic fertilizer industries establishment and price subsidy to farmers purchasing organic fertilizers. Study shows that these programs are effective to reduce soil health deterioration by making nutrient rich manure available at local level. Moreover, it has helped to reduce dependency of fertilizers on other countries and to promote sustainable agriculture. Altogether 1495 vermi-compost pits were constructed and 33746 cattle sheds were improved all over the country till FY 2072/73. Converting farm and household organic wastes into organic manure, improvement of the nutrient content of FYM, utilization of cattle urine for plant protection measures were the benefits of these programs. Furthermore, in long run it helps to create green economy by reducing pollution by keeping environment safe and clean.
\end{abstract}

Key words: Organic fertilizer, soil health, vermi-compost, cattle shed

\section{INTRODUCTION}

Green revolution of 1960s tremendously enhanced the agricultural production mainly due to the abundant use of chemical fertilizers and pesticides. However, unilateral use of chemical fertilizers and pesticides, devoid of organic sources led to gradual deterioration of soil health, putting agricultural productivity at risk. Nepal, predominantly, is an agrarian country. It contributes one third to gross domestic product (GDP) and provides employment to two third of country's population. With the advent of green revolution, use of chemicals has increased in Nepal over the years. Increased use of chemicals has increased the soil pH and deteriorated the soil health. However, farmers now have realized the disadvantages of chemical fertilizers and pesticides and are trying to adopt healthy agricultural practices. Minimization of chemicals used and encouraging farmers towards organic fertilizer has been the priority of Ministry of Agricultural Development (MoAD) over the past years.

Agriculture has been rooted since long in the country with rich heritage of eco-friendly agricultural technologies. Farming in the hills is based on compost and Farm yard manure (FYM) application, which are the main external source of plant nutrients (Sherchan and Gurung 1996). In Nepal,

1 Agriculture Extension Officer, Department of Agriculture Hariharbhawan, Lalitpur

Email: sujanamgai@gmail.com

2 Senior Agriculture Economist, Department of Agriculture Hariharbhawan, Lalitpur

3 Senior Agriculture Economist, Agribusiness Promotion Program, Hariharbhawan, Lalitpur

4 Agriculture Extension Officer, Department of Agriculture Hariharbhawan, Lalitpur 
compost is prepared from plant materials and animal dung whereas FYM is prepared from animal dung only. FYM refers to the decomposed mixture of dung and urine of farm animals along with litter and left over material from roughages or fodder fed to the cattle. On an average well decomposed $\mathrm{FYM}$ contains 0.5 percent $\mathrm{N}, 0.2$ percent $\mathrm{P}_{2} \mathrm{O}_{5}$ and 0.5 percent $\mathrm{K}_{2} \mathrm{O}$. The entire amount of nutrients present in farmyard manure is not available immediately. About 30 percent of nitrogen, 60 to 70 percent of phosphorus and 70 percent of potassium are available to the first crop. The present method of preparing farmyard manure by the farmers is defective. Urine, which is wasted, contains one per centnitrogen and 1.35 percent potassium. Nitrogen present in urine is mostly in the form of urea which is subject to volatilization loss. During storage nutrients are lost due to leaching and volatilization. Although it is practically impossible to avoid losses altogether, it can be reduced by following improved method of farmyard manure preparation. The existing practice of leaving manure in small heaps scattered in the field for a very long period leads to loss of nutrients. These losses can be reduced by spreading the manure and incorporating immediately after application, by ploughing (TNAU AGRITECH PORTAL, 2017).

Due to unavailability on adequate amount of chemical fertilizers in time and subsequent increase in the price of chemical fertilizers, increasing the use of organic fertilizers has became the only alternative for farmers to fulfill plant nutrients demand and to sustain soil fertility. For country like Nepal where transportation is difficult and supply of chemical fertilizer is entirely dependent on import, preparation and utilization of organic fertilizer at local level is very important to follow sustainable agricultural practices. However, scientific method of composting is not properly followed by farmers.Collecting of litter and dumping in a pit itself is called composting by most of farmers (Jaishy et. al. 1997). The manure is not turned over and loss of nutrients by leaching and runoff is high. Sharma, 1983 as cited by Khadka and Chanda 1987, estimated a loss of 50\% nitrogen and $90 \%$ potash from compost heaps, particularly during the rainy season.

Soil health is deteriorated from various factors; indiscriminate use of chemical fertilizers/pesticides, regular cultivation of crops which demand higher nutrients, no crop rotation, lower/unmanaged use of farm yard manure (FYM) etc. Improper/unmanaged used of FYM leads to loss of nutrients. So, to minimize the losses and to reduce the risk factor of soil health deterioration and to promote soil environment; MoAD has implemented program for promotion of organic fertilizer use. Among various organic practices vermi-culture technology, cattle shed improvement program, organic fertilizer production plant establishment program and price subsidy in purchase of organic fertilizer programs have been implemented in the country. There is no chemical fertilizer factory in Nepal and the present combined demand of urea, DAP and MoP is 785,000 tons per annum creating a considerable demand and supply gap. This justifies the major concern of MoAD to promote organic fertilizers (MoAD, 2015/16).

\section{METHODOLOGY}

The review was based on the secondary information. The secondary data were collected from the various publications of Ministry of Agriculture Development (MOAD) and Soil Management Directorate (SMD). Similarly case study report has been taken from District Agriculture Development Office (DADO), Sindhuli.

\section{RESULT AND DISCUSSION}

\section{PROGRAM ON SOIL HEALTH IMPROVEMENT}

With the aim of enhancing food security by promoting organic production and reducing the dependency on imported chemical fertilizers, Soil Management Directorate (SMD) in 
co-ordination with District Agriculture Development Offices (DADOs) has initiated various programs under Department of Agriculture (DoA), as discussed below.

\section{A. Vermi-compost Production Program}

Vermi-composting is an excellent technique for recycling green waste using earthworms. As many as 5,500 species of earthworms have been described worldwide. There are 12 species commonly found in Nepal. Commonly used earthworms for vermi-composting in Nepal are Eisenia foetida, Perionyx excavatus, and Lampito mauritii. They convert organic matter both physically and chemically to increase the soil porosity, and therefore, they are also called as 'ecosystem engineers' (Pandey, 2012).

Table 1: Earthworm species commonly found in Nepal.

\begin{tabular}{|l|l|l|}
\hline Alolobophora caliginosa & Lumbricus spp. & Metaphire posthuma \\
\hline Eutyphoeus napalensis & Octochaetona beatrix & Megascolex spp. \\
\hline E pharpingianus & Perionyx macintoshii & Lampitto mauriti \\
\hline E lippus & Drawida nepalensis & Perionyx fabats \\
\hline
\end{tabular}

(Source: Pandey, 2012)

Considering the higher price of chemical fertilizers and low purchasing power of farmers, DoA has launched the vermi-compost production program to enhance availability of organic fertilizers at farm level since FY 2014/15.

\section{Modality of program}

Farmer group or co-operatives of districts in co-ordination with respective DADOs can make vermi-pit for production of vermi-compost at local level. Vermi-pits should be constructed in cluster and amount of NPR 25,000 per household or $50 \%$ of the cost incurred whichever is less, is provided as subsidy.

\section{Program effects}

- 1495 vermi-compost pits have been constructed; 707 in FY 2014/15 and 788 in FY 2015/16.

- 1495 households were benefited

- It helped in cleaning the environment by utilization of organic wastes from household and farm as raw material for the preparation of vermi-compost.

(Source: SMD, 2015/16)

\section{B. Cattle Shed Improvement Program}

There is an increasing trend of youth out migration for employment in rural community creating a deficiency in farm work force. Consequently, rearing large herds and managing wastes produced from them, as done traditionally, has became more challenging in rural communities. Moreover, due to the improper construction of sheds, urine and water flows towards the animals and stagnate in pools deteriorating the quality of urine, cattle manure and litter which further has a negative impact on the quality of compost produced using it. Realizing these facts, 
DoA had initiated the cattle shed improvement as a mission program in FY 2013/14, aiming effective management of cattle manure and urine by improving the shed floor and urine collection. These practices along with the proper composting and application in soil has led to better soil health and crop production, improving rural environmental.

Modality of program

Farmer group or co-operatives of districts in co-ordination with respective DADOs can improve cattle shed floor along with the construction of urine collection tank and shed for cattle dung (as specified in annex 2). For this work program provides subsidy amount of NPR 5,200 per household or $50 \%$ of the cost incurred whichever is less.

Program implementation

- 33746 improved cattle shed were constructed till FY 2015/16.

- 33746 households were benefited

Program long term effects

- Improves the nutrient content of FYM/protects nutrients loss

- Cattle urine can be used on plant protection measures

- Promote the soil health

- Promote food security through sustainable agriculture development

(Source:SMD, 2015/16)

\section{Case of Cattle Shed Improvement Program in Sindhuli District of Nepal}

Before the program, farmers were not familiar with the benefits of improved shed management. They were doing composting practices in their traditional way; collecting cattle dung in unmanaged way, which was left in direct contact of sunlight and rain. Cattle urine normally infiltrate from the shed as there was no cemented floor in the shed. After implementation of mission program farmers became familiar with the nutrient loss incurred from their practices and thus, were motivated for cattle shed improvement. With the support of District Agriculture Development Office, farmers constructed the improved cattle shed consisting urine canal, urine collection tank and a shed for dung too. Farmers started using this improved manure and urine in their field. Subsequently, soil became more fertile with time and crops started yielding higher. They found significant difference in crop production and soil health after adopting this practice. Mr. Buddhiraj Shrestha, one of the farmers of Ranichuri VDC-5 of Sindhuli district, said that they became aware of the importance of proper management of cattle manure and urine with the intervention of program. He emphasized cattle urine also nourished the soil, increase the microbial activities and disinfect the soil creating better soil health and higher crop yield.

(Source, DADO, 2014/15)

Besides these, in order to promote green environment through farm waste management, MoAD has promoted establishment of organic fertilizers production plant by providing 50 percent subsidy for entrepreneurs. By 2015/16, a total of 25 organic fertilizer plants with annual production capacity of $100600 \mathrm{mt}$ were established (Table 2). 
Table 2: Status of Organic Fertilizer Manufacturers in Nepal.

\begin{tabular}{|c|c|c|}
\hline S.N. & Name of organic fertilizer manufacturers & $\begin{array}{c}\text { Production } \\
\text { capacity } \\
\text { (MT/year). }\end{array}$ \\
\hline 1 & Bansun Agro Organics Pvt. Ltd, Chitwan & 5000 \\
\hline 2 & Tribeni Bio Research and Development Center Pvt. Ltd, Bara & 1000 \\
\hline 3 & Prakritik Susma Jibanu fertilizer industry, Rupandehi & 300 \\
\hline 4 & Small Farmer Agriculture Cooperatives Ltd, Dhanusa & 1000 \\
\hline 5 & Sahayogi Saving and Credit Cooperative Ltd, Rautahat & 1000 \\
\hline 6 & Organic Agriculture Production Center, Chitwan & 5000 \\
\hline 7 & Lumbini Agro Products and Research Center, Rupandehi & 5000 \\
\hline 8 & Janakpur Fertilizers Industries, Morang & 10000 \\
\hline 9 & Buddha Organic Fertilizer Industry, Dhanusa & 10000 \\
\hline 10 & Praramva Bio Tech Pvt. Ltd, Kathmandu & 300 \\
\hline 11 & Lumbini Agro Organic Fertilizer Pvt. Ltd, Rupandehi & 1000 \\
\hline 12 & Nepal Integrated Model Agro Firm Pvt. Ltd, Kavrepalanchowk & 5000 \\
\hline 13 & Unique Bio Tech Organic Pvt. Ltd, Chitwan & 20000 \\
\hline 14 & Kanchan Organic Fertilizer Industry, Kanchanpur & 2000 \\
\hline 15 & Kishan Agriculture Cooperatives Ltd, Siraha & 2000 \\
\hline 16 & Manakamana Agro Organic Fertilizer Industry Pvt. Ltd, Chitwan & 1000 \\
\hline 17 & Suryasakti Supar Organic Fertilizer Production Center, Dang & 5000 \\
\hline 18 & Nepalese Waste Management, Mustang & 500 \\
\hline 19 & Annapura Agriculture Fertilizer Industry, Morang & 10000 \\
\hline 20 & Buddha Organic Fertilizer Industry, Mahendranagar & \\
\hline 21 & Eco Nest Technology Pvt Ltd. Kaski & 2800 \\
\hline 22 & Sauvagya Organic Fertilizer Industry, Rupandehi & 3000 \\
\hline 23 & Uchit Biological Fertilizer Industry, Lalitpur & 700 \\
\hline 24 & National Biotech Pvt. Ltd, Lalitpur & 5000 \\
\hline \multirow[t]{2}{*}{25} & Northfield Organic Fertilizer Factory, Gorkha & 4000 \\
\hline & Total & 100600 \\
\hline
\end{tabular}

Similarly, to promote organic fertilizers produced from the subsidized plants, MoAD is providing price subsidy to the farmers purchasing the organic fertilizers. MoAD provides NPR 10 per $\mathrm{kg}$ or 50 
percent of the sales price whichever is less, as subsidy on purchase of organic fertilizers. Amount of subsidized organic fertilizer distributed is listed in table 3.

Table 3: Distributions of subsidized organic fertilizers in Nepal.

\begin{tabular}{lcc}
\hline $\begin{array}{c}\text { Fiscal } \\
\text { Year }\end{array}$ & $\begin{array}{c}\text { Targeted quantity of subsidized organic } \\
\text { fertilizer (MT) }\end{array}$ & $\begin{array}{c}\text { Quantity of subsidized organic } \\
\text { fertilizer distributed (MT) }\end{array}$ \\
\hline $2011 / 12$ & 788 & 788 \\
$2012 / 13$ & 3977 & 3177 \\
$2013 / 14$ & 10000 & 2615 \\
$2014 / 15$ & 10000 & 1128 \\
$2015 / 16$ & 10000 & 4053 \\
\hline & & (MoAD, 2015/16) \\
Organic fertilizer subsidy program has not been found to be impressive (Table 3). Bulky nature of \\
organic fertilizers and difficulty in transportation, lack of quality assurance of the organic fertilizers \\
are the major issues for its low consumption at farmers' level. Moreover, most of the farmers are \\
producing organic fertilizer locally for their own use.
\end{tabular}

\section{POLICIES AND GUIDELINES FOR ORGANIC PROMOTION}

A few policies and guidelines promulgated for organic promotion in the country are given below:

a. The constitution of Nepal 2015: "Right Regarding Environment and Health" as the fundamental right of a citizen."

b. National Fertilizer Policy, 2002: emphasized IPNS and curtailed direct subsidies, but the state has recently reinstated some price subsidy.

c. National Agriculture Policy, 2004: has a provision to support organic farming and organic products certification (sn31).

d. Agribusiness Promotion Policy, 2006: has provision for development of organic production zone.

e. The 3-Year Interim Plan (2010/11-12/13): promotion of organic farming in strategy (p.70) and support and subsidies on FYM/compost/urine management,

f. Guideline for Organic Fertilizers/ Vermi-compost Production Support Program through Farmer Group and Co-operative, 2014,

This guideline especially focuses on

- Production and use of vermi-compost as well as improved FYM.

- Decreasing the cost of production by minimizing the use of chemical fertilizers.

- Enhancing the production and productivity

- Maintaining the soil fertility by reducing the negative impact of unbalanced use of chemical fertilizers.

- Food and nutritional security through sustainable agriculture production.

g. Guideline for Cattle Shed Improvement Mission Program, 2013 
This guideline especially focus on

- Enhancing the organic practices by production and utilization of improved FYM.

- Decreasing the cost of production by minimizing the use of chemical fertilizers.

- Food and nutritional security through sustainable agriculture production.

h. Guideline for Organic Fertilizer Industry Establishment, 2011

This guideline especially focus on

- Gradually reducing the extensive use of chemical fertilizers and promoting the use of organic fertilizers to maintain the soil fertility.

- Promoting organic fertilizer production factories in the country by providing subsidy.

i. Guideline for Organic and Biological Fertilizer Regulation, 2011

- This guideline provides legal support on organic fertilizer production, testing, import and registration.

- It regulates the import of raw material required for organic fertilizer production.

j. $\quad$ Guideline for Organic Fertilizer Subsidy (District Level), 2015

This guideline especially focus on

- Promotion of organic fertilizer use at local level by providing subsidy to purchase.

- Increase competition among manufacturer for quality supply.

\section{LINKING ORGANIC FERTILIZER WITH RURAL DEVELOPMENT}

Production and promotion of organic fertilizers within the country, on one hand reduces the fertilizer dependency on other countries and decreases expenditure on chemical fertilizers on the other hand. Utilization of organic manures reduces environmental pollution, caused by the use of chemical fertilizers, and helps to create healthy soil and environment which leads to sustainable crop production eventually enhancing household economy and reducing the rural poverty. 


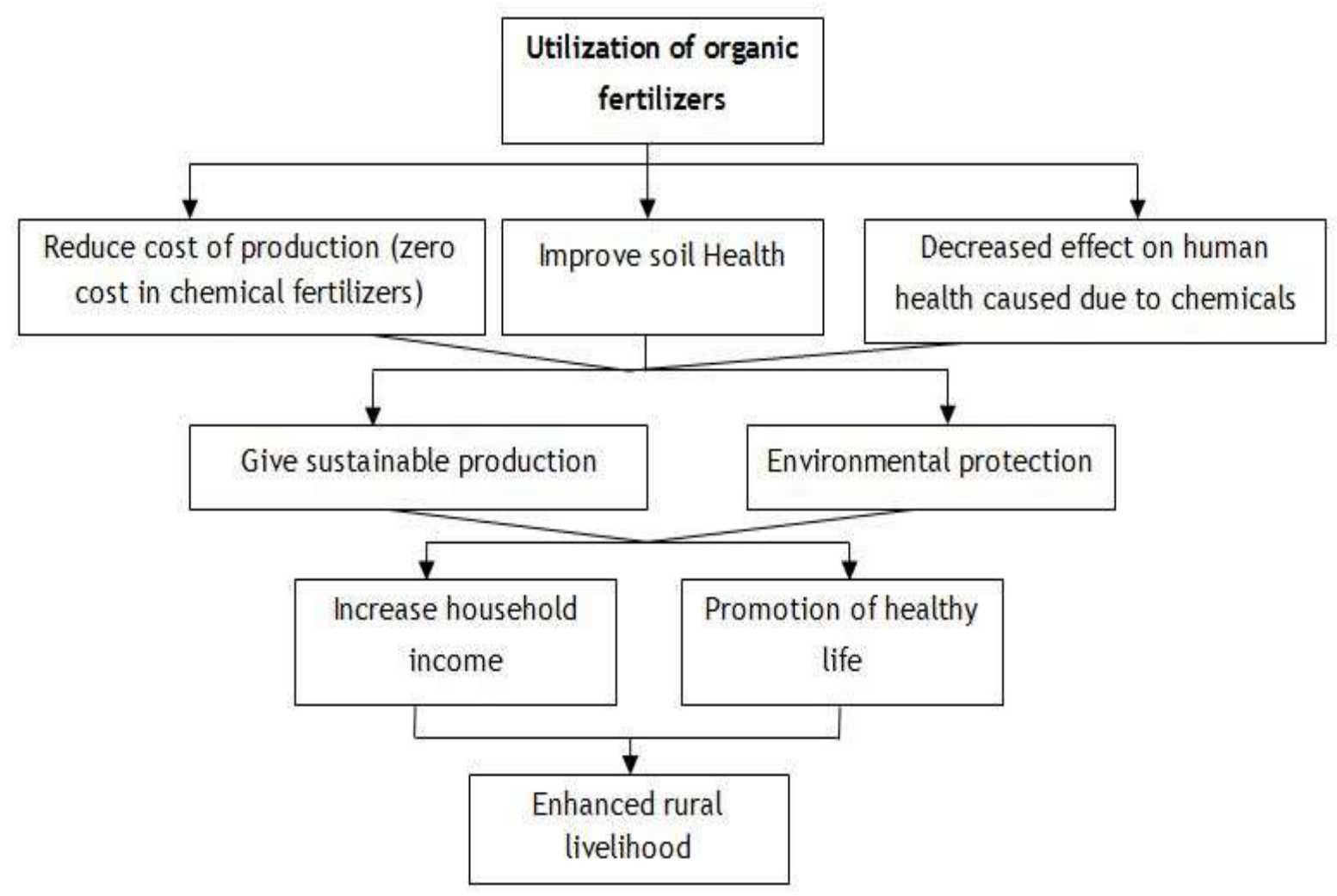

Fig 1: Linking Organic Fertilizer with Rural Development

\section{CONCLUSION AND RECOMMENDATION}

Organic manures, though having less nutrient concentration, contains many of the essential nutrients for plant growth and releases them slowly for longer period. Thus, they have an advantage over chemical fertilizers which contain single to some nutrients which are available to plant for a shorter period. Nepal, in verge of commercialization in agriculture, is facing short in fulfilling the demand of plant nutrients from sources like chemical fertilizers; due to lack of its own production industries, and organic fertilizers; due to less number of production plants and improper management of organic manures at farmer's level. Moreover, soil health is deteriorating in the country due to imbalanced use of chemicals. Considering these facts, MoAD has launched various organic intervention programs; to enhance soil health, to decrease chemical fertilizers dependency and to reduce crop production cost. Among these, vermi-composting, cattle shed improvement, organic fertilizer plant establishment and price subsidy programs are implemented in different FYs within the country.

These programs are in initial phase of implementation. It needs a considerable amount of time to access their impacts, however these programs has been found to be effective to make farmers aware regarding importance of organic manure for enhancing soil health. It has played important 
role to organic waste management and improved crop and livestock husbandry. These programs have created a demonstration effect on village level and thus farmers not involved in programs are inspired to manage the organic manure produced at their household level in proper way.

However, the program price subsidy in purchase of organic fertilizers is not able to meet the target setup by MoAD. This may be due to the current modality of program planning where targets are setup by central agencies. To mitigate this, program planning should be devolved to the local level (DADOs) to create the ownership of farmers and government agencies working at local level and to encourage wider participation. Harsh topography in hilly and mountain regions, unavailability in time and establishment of production plants far away from the demand centers are other problems hindering the successful implementation of programs. These problems can be mitigated by promoting establishment of production plants in and around demand centers and hilly and also in mountain areas rather than establishing in cluster in urban areas.

\section{REFERENCES}

DADO, 2014/15.Annual Progress Report.District Agriculture Development Office, Sindhuli, Nepal.

Jaishy, S.N., N. Mahato, R. Manandhar and K.H. Maskey 1997. Study on use of Compost at farmers level, a report published in Annual Report 20.53154, Soil Testing and Service Section, Dept. of Agriculture.

Khadka, R.J. and S.P. Chanda 1987.Available source of soil nutrients in eastern hills of Nepal. Paper presented at the first review working group meeting on biological technology Nov 15-1 6, Kathmandu, Nepal.

MoAD, 2015/16.Annual Progress Report. Ministry of Agricultural Development.Singha Darbar, Kathmandu, Nepal.

MoAD, 2015/16.Statistical Information on Nepalese Agriculture.Ministry of Agricultural Development.AgriBusiness Promotion and Statistical Division.Singha Darbar, Kathmandu, Nepal.

Panday, 2012. Analysis of Toxic Metals (Cd, Pb, Zn, Cu, Fe) in Earthworm Species (Eisenia foetida, Perionyx excavatus, and Lampito mauritii) and Their Vermi culture, Central Department of Biotechnology, Kirtipur, Nepal

Sherchan, D.P. and G.B. Gurung 1996: Production and management techniques of compost to sustain the hill agricultural production systcm. PAC Technical paper No. 171. Pachribas Agricultural Centre, Nepal

SMD, 2015/16.Annual Progress Report.Soil Management Directorate, Hariharbhawan, Lalitpur, Nepal.

TNAU Agritech Portal. $2017 . \quad$ Organic Farming:

Manures. http://agritech.tnau.ac.in/org_farm/orgfarm_manure.html retrieved on April 8, 2017. 